\title{
Investigating the effective factors on customer loyalty on tourism Agencies using an e- marketing technique: A case study of Iranian tourism agencies
}

\author{
Mohammad Sabet $^{a^{*}}$, Kewmars Fallahi ${ }^{\mathrm{b}}$ and Soheila Sardar Donighi
}

${ }^{a}$ M. Sc ., Business Management, Department of management, Islamic Azad University, Tehran North Branch, Tehran, Iran

${ }^{b}$ Faculty Member, Research Institute for Education, Tehran, Iran

${ }^{c}$ Assistant professor, Department of management, Islamic Azad University, Tehran North Branch, Tehran, Iran

\section{H R O N I C L E}

\begin{tabular}{l}
\hline Article history: \\
Received June 28, 2013 \\
Received in revised format \\
18 October 2013 \\
Accepted 28 October 2013 \\
Available online \\
December 152013 \\
\hline Keywords: \\
Loyalty \\
Satisfaction \\
Trust \\
Navigation functionality \\
Transaction cost \\
Perceived security \\
E-marketing, Tourism
\end{tabular}

\section{Introduction}

During the past few years, information technology, modern technologies, and internet have attracted much attention of many researchers, policy makers, and activists of the arena. As a result, there appeared some accepted theoretical frameworks applied by researchers to study the way of applying these technologies and their effects on commerce communities. In e-commerce, one may design websites to communicate with the customers more efficiently, enhance consumption, and achieve purchase repetition in the future through surveying internet consumers' behavior and recognition of effective factors in their purchase behavior. In addition, the virtual space characteristics may be

*Corresponding author.

E-mail addresses: mod.sabet@gmail.com (M. Sabet) 
applied to use relational marketing; for example, internet instruments including e-mail can be implemented to achieve the customer feedback and react it in a necessary and efficient way. Emarketing has paved the way for this purpose through new facilities. E-marketing in firms and business units can change their nature and identity around the world. Because of increase in electronic communication and the speed of internet, the new electronic ways of marketing rapidly growing and attract companies for on-line investment. E-commerce is an efficient and cheap instrument for companies to enter the new markets and to achieve competitive advantages. The main advantage of this marketing is to reduce risk level and cost of entering the new markets.

Marketing has stepped on a new stage in which marketers do not restrict themselves just to find new customers, but they aim at demand management through developing and leading their customers toward higher steps of the loyalty ladder to the organizations. Today, customer satisfaction is not enough for companies but they must ensure that customers are loyal. The purpose of this paradigm is to build long term and mutual relationships with practitioner groups and more importantly with customers. This helps to preserve more customers and to obtain long-term advantages and as a result, the companies increase their market share and benefits. The satisfaction era has changed into the loyalty era, which consists of customer loyalty, employees' loyalty, management loyalty, loyalty to society, principles goals beliefs, etc. Many researches revealed that satisfaction is not the end key for success and benefit. In fact, the marketing concepts which emphasized on satisfaction earlier did not recognize it anymore; but they insisted that happy and satisfied customers who feel loyal to organizations are beneficial and long term capitals.

Therefore, this kind of studies may help companies and institutions provide their products and services in cyber space, through determining the efficient factors in customers' behavior who purchase their required goods and services using internet. Marketing knowledge authorities have pointed to many loyalty advantages.

Customer's loyalty to trade marks lead to positive oral propaganda, basic barriers against new competitors, empowering firms to respond competitive threats, more sale and income and finally customers' less sensitivity to competitors' marketing activities. Numerous loyal customers to a trade mark are assumed as a firm's asset and the main indicator of the trademark's special value. The loyal customers are less sensitive to price changes. Most of loyalty scholars have concentrated on repetition of purchasing (Meller et al. 2006).

Trademark loyalty consists of two components: behavior loyalty and attitude loyalty. Mellenz et al. (1996) define the behavior loyalty as being loyal to a trade mark through considerable purchase in a specific period of time; and the attitude loyalty as purchase intention or commitment, based on preference expression. Many scholars believe that behavior loyalty may not be the real cause of purchase by itself; hence, the attitude aspects should also be considered (BaloGlu, 2002). Lessler and Little (1997) concluded that trademark loyalty is associated with product complexity. They suggested that repurchase behavior with high problematic activities represent trademark loyalty; while repurchasing behavior with low problematic activities represent habitual purchasing behavior (Quester, \& Lim, 2003).

Loyalty to trademark depending on the market type is divided into three different groups: temporary goods market, durable goods market; and service market. Since there are more interpersonal relationships in service section between service provider and customer, loyalty is of special importance in this regard (Meller et al., 2006). Trademark loyalty studies in services market are less than those in goods loyalty. Services market includes services to airlines consumer, legal services, as well as accounting and communication services. Sentiments play essential role in trademark loyalty, especially in providing satisfaction. It is the primary key to support service providers (Bennett et al., 2005). There is a high loyalty level in services market relative to temporary goods market. Intermarket relationship perception requires that marketers would not devote resources to markets in 
which goals are not realizable (Bennett et al., 2005). In this paper, we study effective factors on customer loyalty with and e-marketing approach in Tehran Tourism agencies.

\section{Literature review}

\subsection{Loyalty}

Loyalty is an ancient term, which describes the profound commitment to family and friends and enters the marketing terms as "trademark loyalty". Customer loyalty has been interpreted in terms of various aspects. Loyalty to trademark, goods etc. are among the interpretations. Oliver (1999) defines loyalty as having a profound commitment to repurchase or support an interested goods or services, which lead to repetition of purchasing a trademark or products of a trademark, despite of situational effects and the competitors' marketing attempts. Some loyalty researchers define it as a behavior or attitude and some others as a combination of them. The important point is the consensus in all definitions regardless of different approaches.

Today, specifying and predicting the customers' needs is necessary for commercial agencies in order to achieve competition advantage and market sectoring. Customer is the primary factor in enhancing the organization agility, goal setting, strategies, and resources are around the axis of customer attraction and preservation and enhancement of the customer loyalty is a strategic challenge for the firms' concern about keeping their competitive position. Oliver (1999) defines the loyalty concept as preserving the profound commitment to repurchase a good or service in future, despite of the situational effects and marketing attempts which may potentially change the customers behavior.

Any definition for loyalty includes the following,

- Customer behavior or repurchasing;

- Customer attitude or commitment and trust;

- Access which is along with numerous choices for purchase.

With regard to attitude approach, there are three kinds of loyalty:

1- Cognitive loyalty: leads to customer behavior and relates to customer belief.

2- Sentimental loyalty: leads to customer commitment and trust and relates to customer sentiments.

3- Active loyalty: relates to the customer intention to purchase in future (Carolyn et al. 2002).

It is of great importance to know that why customers leave us. Although loyal customers are generally satisfied, their satisfaction domain does not necessarily lead to loyalty behaviors. According to Oliver's analysis (1999) the first required step in loyalty formation is satisfaction; however there are other effective factors in customer-organization relationships including: personal decision and social bonds. Johns and Farquhar (2003) suggest that a little customer-centrism increases the possibility of customer preservation (Trasorras et al., 2009).

\subsection{Satisfaction}

Concerning the customer satisfaction, there are varieties of definitions from marketing theorists. Jamal and Nasser (2002) define customer satisfaction as the customer's sentiment or attitude toward a product after using it. They explain that customer satisfaction is the main result of the marketer activity as a relationship among various purchase behavior process. For instance, if a particular customer is satisfied of specific services, he/she will probably repeat the purchase. The satisfied customers speak probably about their experiences; as a result, they engage in positive oral propaganda. However, unsatisfied customers probably disconnect the company and engage in negative oral propaganda. 
Moreover, behaviors such as repurchase and oral propaganda influence directly the company's survival and benefits (Jamal \& Nasser, 2002). Blanchard and Galvez believe that customer satisfaction is the result of his/her perception achieved during a relation or trade; so that the price equals to proportion of the service quality to customer price and expenditure (Hallowell, 1996). Many authorities agree on this definition of the customer satisfaction: "the result of comparing the customer expectances before purchase with the actual perceived performance and the cost" (Beerli et al., 2004).

\subsection{Trust}

Fukuyama (1995) defines trust as expectance of the regular, acceptable and helping behaviors in a society, which are formed based on common criteria among some part of the population. Fukuyama (1995) believes that technological changes increase the role of trust in perception of commercial behaviors. According to a more precise definition, trust in a trade mark means a customer's tendency to reliance on the mark capabilities in performing the specified duties (Fukuyama, 1995).

Singh, and Sirdeshmukh (2000) present a model, which introduces the trust as an effective factor customer satisfaction (in turn is a function of loyalty). This model was designed by Chaudhuri, and Holbrook. (2001) where loyalty has been confirmed as they defined.

Generally, the effective factors on customer trust are divided as:

- Individual factors affecting the customer trust;

- The company-related and effective factors on customer trust;

- Factors related to marketing combination;

- Infrastructural factors which affect customer trust.

By individual factors, we mean those factors, which related to customer and influence his/her trust in e-commerce. Kim et al. (2004) refer to consumer behavior aspect in their multi-dimensional processcentered model as well as to demographic characteristics, experience etc. which affect the consumer's trust. The company related factors are those related to the company or the websites which supply goods and services through internet. For example, Shankar et al. have introduced product quality as one of the three basic trust principles. In addition, Dial et al. (1999) pointed to selling way in trust pyramid as one of the main factors for trust creating. Some researchers assume that after sale services and specific policy for backing the purchased goods are efficient in promotion of customers' trust in e-commerce (Tan \& Sutherland, 2004). Infrastructural variables are those related to e-commerce environment and they pave the way for commerce in virtual space. Various researches have emphasized on infrastructural factors as effective variables of the customer trust in e-commerce.

Hemphill (2002) was among the scholars who believe in regular, legal and lawful infrastructure for creating trust among customers. Kim et al. (2011) point to multi-dimensional process-centric model, creation of trust in institutional aspect (legal and lawful infrastructures and financial infrastructures) and technology (IT and software characteristics which lead to secure and efficient transactions). Bin Omar et al (2011) emphasize confirmations (financial infrastructures) as an infrastructural factor in creating trust among the customers.

\subsection{Perceived Security}

Security means getting ride of risk or fear of threats which may lead to financial damages as well as data base or network damages in the forms of data removal, deletion and overture (Belanger et al., 2002). Polatoglu and Ekin (2001) studied the internet security effect in Turkey and considered validity, trust and privacy as requirements for security perception. Validity refers to correctness, precision and appropriateness of services. Internet technology rapid development made many banks change their ports, which in turn reduced customers' concerns (Morgan \& Hunt, 1994). 
Munoz-Leiva et al. (2010) studied internet security and suggested that validity is the main perceived security aspect. Confidence covers categories such as risk immunity, threat or hurt risk against individuals and their assets both knowingly and unknowingly. Privacy discusses about the possibility for internet companies to collect and abuse data: the move concerns about the customers internet privacy, and more regulations and policies in this regard increase the customers trust in company and at the same time reduce the perceived risk and customers worries about internet purchase (Roca et al., 2009).

\subsection{Navigation functionality}

The last three decades of communication and technology have been named the Communication Technology Revolution Era. Internet has changed the social and individual life. Web is a standard instrument for commerce to connect each other and with customers; that is why website designing and efficiency has become very significant (Batra \& Bishu, 2007). Bar Illan (2005) defines web as a set of documents connected by super texts. Web is one of the greatest inventions of the $20^{\text {th }}$ century and its rapid development both facilitates communication and affects all human's life aspect.

Most of website are developing and embracing more information and services. These information and service contain a wide spread applications including business management and purchase and entertainment, which provided many opportunities for merchants and many services for users. At the same time web is complex information and requires special interaction and user interface.

Meanwhile, there appear some important questions including: which website is reliable? Which website does provide better services? Websites evaluation and ranking seems necessary. Content and text assessment has been noticed for a long time, however web has led to new aspects and applications each of which needs a separate study opportunity (Tate, 2010). Studies revealed that $60 \%$ of individuals do not find what they want in websites. That is way many web visits are unwillingly and repetitive and waste of energy and time. Evaluation of the website process, data collection as well as qualitative and quantitative data assessment is the basis for deciding how a website meets the goals. In this way, the website designers promoted the related quality. Website evaluation or assessing its applicability has been considered since many years ago and many criteria have been introduced in this regard (Instone, 1997). Table 1 shows some studies conducted in web evaluation.

\section{Table 1}

Studies in web evaluation

\begin{tabular}{l|ll}
\hline Researcher & Year & Research Area \\
\hline Alastrair & 1997 & Required indices for websites designing and evaluation, in general \\
\hline Krug & 2000 & Required indices for websites designing and evaluation, in general \\
\hline Welling and White & 2006 & Evaluation of websites efficiency at organization or economic agency level \\
\hline Huang et al. & 2006 & Evaluation of websites efficiency at organization or economic agency level \\
\hline Büyüközkan et al. & 2007 & $\quad$ Evaluation of academic website quality and virtual education \\
\hline Olsina et al. & 1999 & Evaluation of academic website quality and virtual education \\
\hline Merwe \& Bekker & 2003 & e-Commerce websites evaluation \\
\hline Oppenheim \& Ward & 2006 & e-Commerce websites evaluation \\
\hline Bilsel et al. & 2006 & $\begin{array}{l}\text { Evaluation of websites related to health and human services } \\
\text { Welch \& Pandey }\end{array}$ \\
\hline
\end{tabular}

\subsection{Transaction cost}

Commercial data exchange happens in a standardized model among computers. During data exchange, data are organized based on a model determined by the exchangers; so that they allow 
computers exchange data without any external intervention or any more data. There are three main reasons for applying electronic data exchange:

1- Reduction of paper trades;

2- Reduction of new data input;

3- Speed and Simplicity.

Internet business is cheaper than establishing a retail shop, and provides more access to customers. Moreover, in this regard customer access cost is less than that in usual propaganda methods.

\section{Conceptual model and the research hypotheses}

Fig. 1 shows the conceptual model of the research.

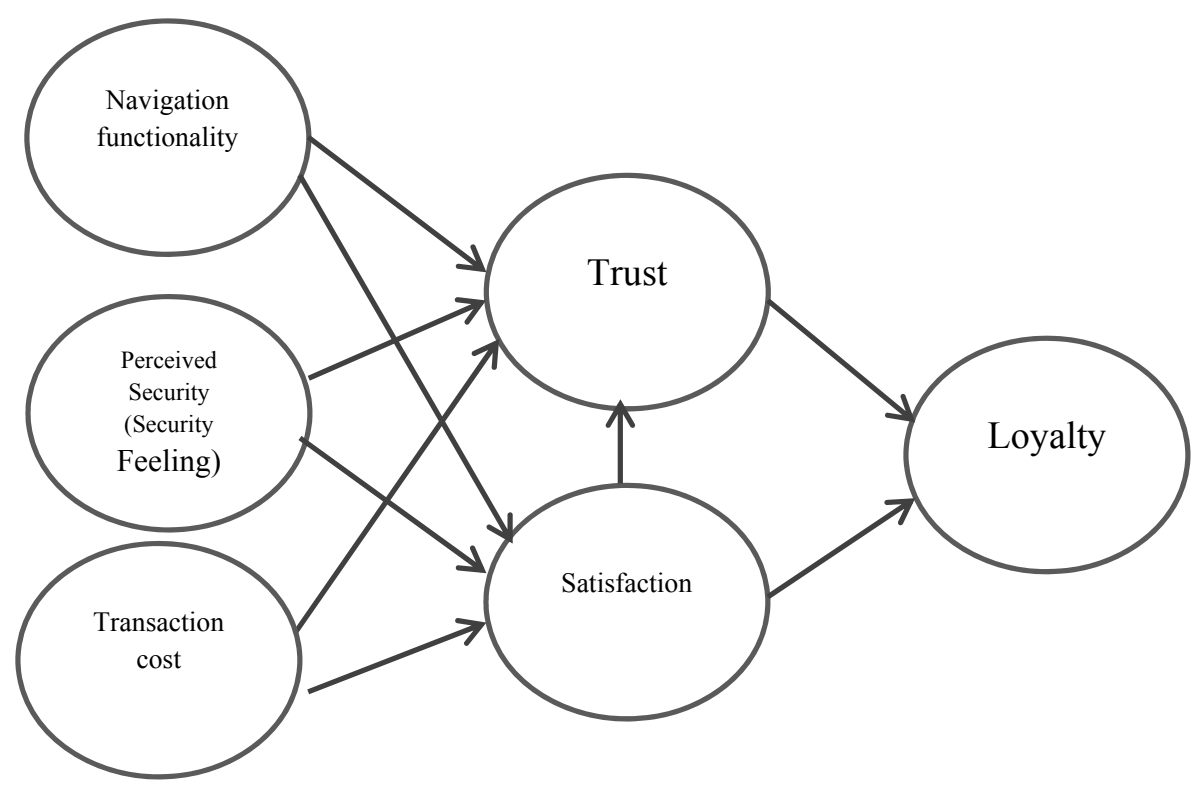

Fig. 1. The research conceptual model

This model has been adopted from the work published earlier by Kim et al. (2011).

\section{Hypotheses}

H1: capability of searching in Tehran tourism agencies' website affects the customer trust.

H2: capability of searching in Tehran tourism agencies' website affects the customer satisfaction.

H3: The perceived security in Tehran tourism agencies' website affects the customer trust.

H4: The perceived security in Tehran tourism agencies' website affects the customer satisfaction.

H5: The transaction cost in Tehran tourism agencies' website affects the customer trust.

H6: The transaction cost in Tehran tourism agencies' website affects the customer satisfaction.

H7: satisfaction from Tehran tourism agencies' website affects the customer trust.

H8: trust in Tehran tourism agencies' website affects the customer loyalty.

H9: satisfaction from Tehran tourism agencies' website affects the customer loyalty. 


\section{Research methodology}

\subsection{Statistical population and samples}

At the present study, statistical population consists of all customers of tourism agencies in Tehran. Morgan table was used to determine the number samples. Since the population is unlimited the number of samples calculated as 384 individuals. The clustering probable sampling was applied in sampling process. Forty questionnaires were distributed among each agency's customers in nonrandom (access-based) way all of which were completed and returned. The collected data were analyzed. Among the interviewees $47 \%$ were male and 53\% were female; $72 \%$ were single and $28 \%$ married; $67 \%$ were at the age below $30,25 \%$ between 30 and $40,6 \%$ between 40 and 50 and 2\% were at the age of over 50 years. Concerning the educational level, $15 \%$ of respondents were postdiploma and lower, $48 \%$ graduated, $31 \%$ post graduated and 65 were $\mathrm{Ph} . \mathrm{D}$. Concerning familiarity with tourism websites internet services, the research interviewees had experiences as: $20 \%$ less than one year; $58 \%$ between $1-5$ years, $13 \%$ between $5-10$ years and $9 \%$ over 10 years.

\subsection{Variable measurement instrument}

In this research, the closed questionnaire has been applied. In the questionnaire Likert's five-scale instrument was used. The Cronbach's alpha was applied to measure its reliability and its validity was evaluated using the experts' opinions and the construct validity was measured using confirmatory factor analysis (Table 2).

\section{Table 2}

Results of confirmatory factor analysis and Cronbach alpha

\begin{tabular}{|c|c|c|c|}
\hline Variable & Item & Cronbach alphas & Factor load \\
\hline \multirow{6}{*}{$\begin{array}{l}\text { Navigation } \\
\text { functionality }\end{array}$} & Tourism agencies websites can be used to purchase tourist goods as online serves. & \multirow{6}{*}{0.767} & 0.670 \\
\hline & Keyword search in website of the tourism agency was equal to searching the website & & 0.562 \\
\hline & Aid menus and existing links in website of the tourism agency were helpful & & 0.614 \\
\hline & The highest level of technology was applied to design websites and the related facilities & & 0.810 \\
\hline & The tourism agency's website had a good operational efficiency and yield. & & 0.775 \\
\hline & Words and images were rapidly transferred in website & & 0.599 \\
\hline \multirow{3}{*}{ Perceived security } & Credit card application was secure in purchasing online tourism goods & \multirow{3}{*}{0.832} & 0.787 \\
\hline & My private information are secured in online application & & 0.879 \\
\hline & Online tourist companies are reliable concerning users privacy & & 0.922 \\
\hline \multirow{5}{*}{ Transaction cost } & Online purchase is economic & \multirow{5}{*}{0.795} & 0.840 \\
\hline & Comparing with non-internet purchase, online purchase leads to expenditure save & & 0.700 \\
\hline & E-commerce has higher discount relative to non-internet purchase & & 0.523 \\
\hline & Considering price and other expenditures, online purchase is more appropriate & & 0.826 \\
\hline & E-commerce has its own expenditures, however it provides acceptable and logical services and quality & & 0.757 \\
\hline \multirow{3}{*}{ Trust } & Tourism online sites are honest and defect less & \multirow{3}{*}{0.834} & 0.818 \\
\hline & Tourism online sites are reliable & & 0.909 \\
\hline & Tourism online sites are honest & & 0.871 \\
\hline \multirow{4}{*}{ Satisfaction } & Generally, online purchase is satisfactory & \multirow{4}{*}{0.779} & 0.799 \\
\hline & Content of online tourism sites meet my information needs & & 0.752 \\
\hline & Purchasing the selected good was easy & & 0.750 \\
\hline & Online purchase made me more satisfied in comparison with off line purchase (by phone or presence). & & 0.800 \\
\hline \multirow{4}{*}{ Loyalty } & I suggest online purchase of the tourism products & \multirow{4}{*}{0.896} & 0.881 \\
\hline & Online purchase is the best choice for tourism goods purchase & & 0.851 \\
\hline & I apply online purchase of tourism products, even if it is possible to use alternative purchase forms & & 0.907 \\
\hline & I prefer online purchase over any other purchasing forms & & 0.851 \\
\hline
\end{tabular}

As we can observe from the results of Table 2, the values of Cronbach's alpha $(\alpha>0.7)$ and factor loads $(>0.4)$ calculated through confirmatory factor analysis reveal that the questionnaire items are proper. 


\subsection{Data analysis and hypotheses testing}

In this research the Structural Equations Modeling (SEM) has been used in the form of the PLS to determine coefficients; because the sample size is small and the independent variables have selfcorrelation.

\section{5- Results}

In this research, we have firstly used Kolmogorov-Smirnov test to assess data normality. The results reveal that the research data are normal (Table 3).

Table 3

Normality test of the research variables

\begin{tabular}{cccc}
\hline Variables & Z statistics & Meaning fullness level & Hypothesis result \\
\hline Loyalty & 1.351 & 0.053 & Normal \\
Navigation functionality & 1.086 & 0.189 & Normal \\
Perceived security & 0.825 & 0.504 & Normal \\
Satisfaction & 1.211 & 0.091 & Normal \\
transaction cost & 1.101 & 0.269 & Normal \\
Trust & 1.201 & 0.097 & Normal \\
\hline
\end{tabular}

Fig. 2 shows the SEM in estimation the standard coefficients.

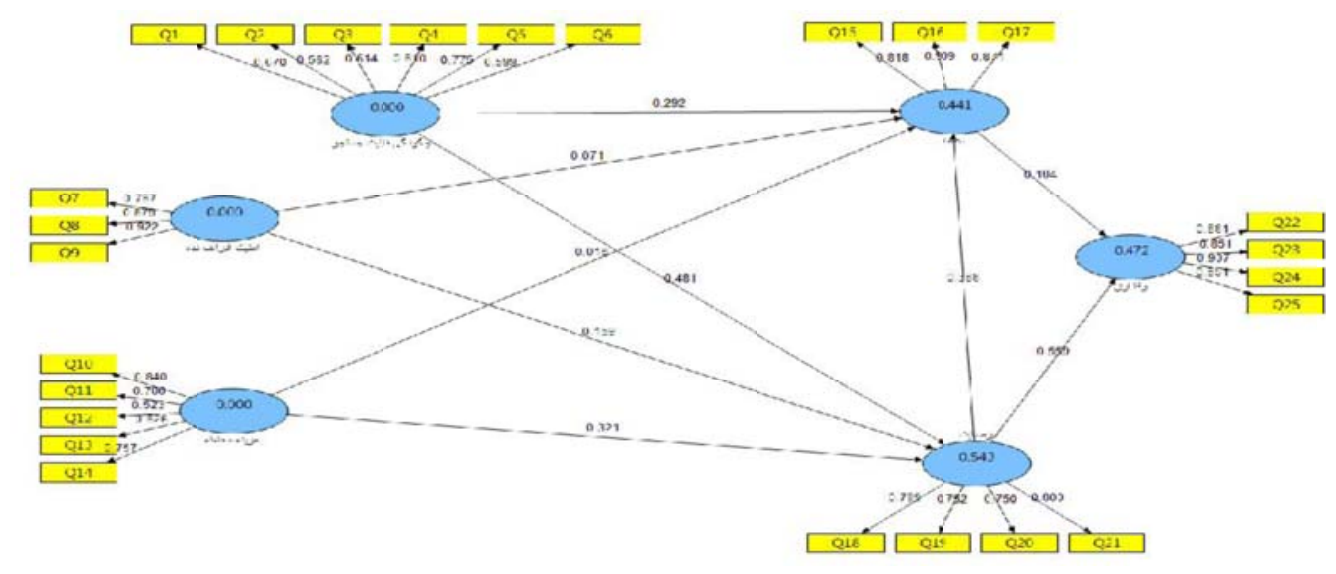

Fig. 2. SEM in estimation of the standard coefficients

To assess model's fit we used various indices including Chi 2 to freedom degree, goodness fit index, root mean of square error assessment comparative fit index, normed fit index, and non-normed fit index. The model's fit indices show that it is in an appropriate situation (Table 4).

\section{Table 4}

Indices of the model fit

\begin{tabular}{lcc}
\hline Index & Model estimations & Limit \\
\hline Chi square/ degree of freedom $\left(\mathrm{X}^{2} / \mathrm{df}\right)$ & 1.648 & $<3$ \\
Goodness of fit index (GFI) & 0.91 & $>0.9$ \\
Root Mean of Square Error Assessment (RMSEA) & 0.082 & $<0.1$ \\
Comparative fit index (CFI) & 0.96 & $>0.9$ \\
Normed fit index (NFI) & 0.93 & $>0.9$ \\
Non-normed fit index (NNFI) & 0.97 & $>0.9$ \\
\hline
\end{tabular}

Table 5 shows the route coefficients and the results of hypotheses test. 
Table 5

Route coefficients and hypotheses tests results

\begin{tabular}{lcccc}
\hline Hypothesis & $(\beta)$ Route coefficient & t statistics & Sig. level & Result \\
\hline $\mathrm{H}_{1}:$ Navigation functionality $\rightarrow$ Trust & 0.292 & 5.685 & $<0.01$ & Confirmed \\
$\mathrm{H}_{2}:$ Navigation functionality $\rightarrow$ Satisfaction & 0.481 & 11.903 & $<0.01$ & Confirmed \\
$\mathrm{H}_{3}:$ Perceived security $\rightarrow$ Trust & 0.071 & 1.344 & $>0.05$ & Rejected \\
$\mathrm{H}_{4}:$ Perceived security $\rightarrow$ Satisfaction & 0.159 & 3.179 & $<0.01$ & Confirmed \\
$\mathrm{H}_{5}:$ Transaction cost $\rightarrow$ Trust & 0.018 & 0.463 & $>0.05$ & Rejected \\
$\mathrm{H}_{6}:$ Transaction cost $\rightarrow$ Satisfaction & 0.321 & 8.121 & $<0.01$ & Confirmed \\
$\mathrm{H}_{7}:$ Satisfaction $\rightarrow$ Trust & 0.388 & 6.436 & $<0.01$ & Confirmed \\
$\mathrm{H}_{8}:$ Trust $\rightarrow$ Loyalty & 0.184 & 2.676 & $<0.01$ & Confirmed \\
$\mathrm{H}_{9}:$ Satisfaction $\rightarrow$ Loyalty & 0.559 & 8.031 & $<0.01$ & Confirmed \\
\hline
\end{tabular}

As you see in table 5 the results reveal that hypotheses 1,2, 4, 6, 7, 8 and 9 are confirmed and hypotheses 3 and 5 rejected. Table 6 shows Pearson correlation coefficients among the hidden variables as well as coefficients of the dependent variables in the model. The meaningfulness or significant level for all correlation coefficients among the variables is $<0.05$

\section{Table 6}

Pearson correlation coefficients related to hidden variables and coefficients of dependent variables determination

\begin{tabular}{|c|c|c|c|c|c|c|c|}
\hline Latent variables & Loyalty & $\begin{array}{c}\text { Search } \\
\text { capability }\end{array}$ & $\begin{array}{c}\text { Perceived } \\
\text { security }\end{array}$ & satisfaction & $\begin{array}{c}\text { transaction } \\
\text { cost }\end{array}$ & Trust & $\begin{array}{l}\text { Determination } \\
\text { coefficient }\left(\mathrm{R}^{2}\right)\end{array}$ \\
\hline Loyalty & 1 & & & & & & 0.472 \\
\hline $\begin{array}{l}\text { Navigation } \\
\text { functionality }\end{array}$ & 0.556 & 1 & & & & & ........ \\
\hline $\begin{array}{l}\text { Perceived } \\
\text { security }\end{array}$ & 0.327 & 0.446 & 1 & & & & .......... \\
\hline Satisfaction & 0.672 & 0.646 & 0.451 & 1 & & & 0.543 \\
\hline Transaction cost & 0.568 & 0.295 & 0.241 & 0.501 & 1 & & .......... \\
\hline Trust & 0.529 & 0.58 & 0.38 & 0.618 & 0.315 & 1 & 0.441 \\
\hline
\end{tabular}

The determination coefficient of dependent variables in the model shows the variance percentage level of a dependent variable, which is explained by the independent variables. The higher level would lead to higher independent variables coefficient effect on the dependent variables. Therefore, the effect of dependent variables is higher on independent variables. The determination coefficient of trust variable was 0.441 , which shows that variables of navigation functionality, perceived security and transaction cost can totally explain $44.1 \%$ of the trust variance. The remaining $55.9 \%$ relates to prediction error and may consist of other efficient factors on trust. This coefficient for satisfaction is 0.543 and shows that the above mentioned variables can explain $54.3 \%$ of the satisfaction variance. Finally, the determination coefficient for loyalty is 0.472 and the changes have been explained using satisfaction and trust directly and website research capability, perceived security and transaction cost indirectly.

\section{Discussion and Conclusion}

Today, tourism industry has changed into a prosperous industry for the countries with tourism attractions. The internet websites is one of the highest information sources in tourism industry. Having one billion users and high information value, the digital information territory is an appropriate opportunity for introducing multi-lingual instrument and multi-media tourism capability. Internet bases are sustainable and provide text and images change and transferring possibility without new expenses. On the other hand, increasing number of internet users and the related bases' high capability and capacity for affecting communities promote tourism industry marketing. In a modern society, most of people are eager and apply online purchase and e-commerce well. Companies are willing to use internet as a key marketing instrument and sale media (Tatnall \& Lepa, 2001). Online users are increasing, but many people are in doubt about entering their personal information in websites 
because they do not rely on e-commerce security (Smith, 2008). A few studies have considered ecommerce in tourism with regard to trust variable. Therefore, the aim of this research was to develop a theoretic model for e-commerce, which combines trust and satisfaction and experiments the infrastructures with possibility of affecting loyalty (which in turn affects the purchase intention). Results of the research shows that 7 out of 9 determined relations among the developed concepts provide positive factor coefficients. The model revealed that if customers consider the website honest, they will purchase tourist services and goods. Yoon (2002) suggested that internet search capability does not affect the website reliability and that online users concern less about sites' performance characteristics. On the other hand, Chen (2006) concluded that the variable affects consumer's general satisfaction and provides a positive medium support; i.e. the higher search capability, the more satisfied would be the consumer. The perceived security guaranteed by online privacy, keeping private information and no-risky payments had a very low positive effect on satisfaction and no effect on trust.

Generally, perceived security has a positive relation with satisfaction but no relation with trust. The reason may be other factors, which were not considered in this study. Hence, more studies are needed to explain the problem. Transaction cost which is basically accompanied by money saving had a positive medium relation with satisfaction but no relation with trust. Concerning the satisfaction, results of this research were in conformity with those of other researches (Lee et al., 2008; Lim \& Kim, 2005; McColl, 2002); but it is not true for trust and the related findings may be case results, i.e. the customers may not have confidence in online purchase, but they may achieve higher levels of satisfaction because of savings. If a customer intends to use off purchase through online buying the tourism services and products, satisfaction will intervene between transaction cost and trust (Lee et al., 2008; Lim \& Kim, 2006; McCole, 2002). Our research reveals that when customers welcome the online purchase, satisfaction probably affects their trust, which is necessary for this purpose (Corbitt et al., 2003; Lanford, 2006). In addition, satisfaction and trust affect positively the loyalty (which in turn affects the customers' behavioral intention with regard to the tourism services and products.

\section{References}

Alastrair, G. (1997). Testing the surf: Criteria for evaluation internet information resource. PublicAccess Computer System Review, 8, 5-23.

Baloglu, S. (2002). Dimensions of customer loyalty: separating friends from well wishers. The Cornell Hotel and Restaurant Administration Quarterly, 43(1), 47-59.

Batra, S., \& Bishu, R. R. (2007). Web usability and evaluation: issues and concerns. In Usability and Internationalization. HCI and Culture (pp. 243-249). Springer Berlin Heidelberg.

Bennett, R., Shargn R. \& Thiele, (2005). The brand loyalty life cycle: Implications for marketers. Journal of Brand Management, 12(4), 250-263.

Beerli, A., Martin, J. D., \& Quintana, A. (2004). A model of customer loyalty in the retail banking market. European Journal of Marketing, 38(1/2), 253-275.

Belanger, F., Hiller, J. S., \& Smith, W. J. (2002). Trustworthiness in electronic commerce: the role of privacy, security, and site attributes. Journal of Strategic Information Systems, 11, 245-270.

Bin Omar, A., Sultan, N., Zaman, K., \& Bibi, N. (2011). Customer perception towards online banking services: Empirical evidence from Pakistan. Journal of Internet Banking and Commerce; 16(2), 124.

Bilsel, R. U., Büyüközkan, G., \& Ruan, D. (2006). A fuzzy preference-ranking model for a quality evaluation of hospital web sites. International Journal of Intelligent Systems, 21(11), 1181-1197.

Büyüközkan, G., Ruan, D., \& Feyzioğlu, O. (2007). Evaluating e-learning web site quality in a fuzzy environment. International Journal of Intelligent Systems,22(5), 567-586.

Chaudhuri, A., \& Holbrook, M. B. (2001). The chain of effects from brand trust and brand affect to brand performance: the role of brand loyalty. Journal of Marketing, 65(2), 81-93.

Chen, C. (2006). Identifying significant factors influencing consumer trust in an online travel site. Information Technology \& Tourism, 8(3/4), 197-214. 
Corbitt, B. J., Thanasankit, T., \& Yi, H. (2003). Trust and ecommerce: a study of consumer perceptions. Electronic Commerce Research and Applications, 2, 203-215.

Oppenheim, C., \& Ward, L. (2006). Evaluation of web sites for B2C e-commerce. Aslib Proceedings, $58,237-260$.

Dayal, S., Landesberg, H., \& Zeisser, M. (1999). How to build trust online. Marketing Management, $64-69$.

Welch, E.W., \& Pandey, S. (2007). Multiple measures of web site effectiveness and their Association with service quality in health and human service agencies. In Proceedings of The 40th Hawaii International Conference on System Science, 107-112.

Fukuyama, F. (1995). Trust, The Free Press, New York, NY.

Hallowell, R. (1996). The relationship of customer satisfaction, customer loyalty and profitability: an empirical study. International Journal of Service Industry Management, 7(4), 27-42.

Huang, W., Le, T., Li, X., \& Gandha, S. (2006). Categorizing web features and functions to evaluate commercial web sites: An assessment framework and an empirical investigation of Australian companies. Industrial Management \& Data Systems, 106(4), 523-539.

Hemphill, T. A. (2002). Electronic commerce and consumer privacy: Establishing online trust in the US digital economy. Business and Society Review, 107(2), 221-239.

Jamal, A., \& Naser, K. (2002). Customer satisfaction and retail banking: an assessment of some of the key antecedents of customer satisfaction in retail banking. European Journal of Marketing, 20(4), 146-160.

Bar-Ilan, J. (2005). What do we know about links and linking? A framework for studying links in academic environments. Information Processing and Management, 41, 973-986.

Instone, K. (1997). "Usability Heuristics for the Web".

Lanford, P. (2006). E-commerce: a trust perspective. International Conference on Internet Computing, 64-70

Lee, K. L., Lee, C. K., Lee, S. K., \& Babin, B. J. (2008). Festivalscapes and patrons' emotions, satisfaction, and loyalty. Journal of Business Research, 61(1), 56-64.

Lim, S. T., \& Kim, J. M. (2006). A study on antecedent variables of preference and loyalty for channels based on the perspective of transaction cost analysis: focused on online travel packages. Journal of Tourism Sciences, 57(5), 341-360.

McCole, P. (2002). The role of trust for electronic commerce in services. International Journal of Contemporary Hospitality Management, 14(2), 81-8

Meller J. J., \& Hansan T. (2006). An Empirical examination of brand loyalty. Journal of Product \& Brand Management, 15(7), 442-449.

Merwe, V.D., \& Bekker, R. (2003). A framework and methodology for evaluating e-commerce web sites. Internet Research: Electronic Networking Applications and Policy, 13, 330-341.

Morgan, R.M., \& Hunt, S. D. (1994). The commitment-trust theory of relationship marketing. Journal of Marketing, 58, 20-38.

Munoz-Leiva F., Luque-Martınez T., \& Sanchez Fernandez J. (2010); How to improve trust toward electronic banking. Online Information Review, 34(6), 907-934.

Kim, M.J., Chung, N., \& Lee, C.K. (2011). The effect of perceived trust on electronic commerce: Shopping online for tourism products and services in South Korea. Journal of Tourism Management, 32, 256-265.

Kim, D. J., Song, Y. I., Braynov, S. B., \& Rao, H. R. (2005). A multidimensional trust formation model in B-to-C e-commerce: a conceptual framework and content analyses of academia/practitioner perspectives. Decision Support Systems, 40(2), 143-165.

Krug, S. (2000). Don't Make Me Think- A Common Sense Approach to Web Usability: Indianapolis: New Rides Publishing.

Polatoglu, V. N., \& Ekin, S. (2001). An empirical investigation of the Turkish consumers' acceptance of internet banking services. International Journal of Bank Marketing, 19(4), 156-165.

Oliver, R. L. (1999). Whence consumer loyalty. Journal of Marketing, 63, 33-44. 
Olsina, L., Godoy, D., Lafuente, G., \& Rossi, G. (1999). Assessing the quality of academic websites: a case study. New Review of Hypermedia and Multimedia, 5(1), 81-103.

Quester, P., \& Lim, A. L. (2003). Product involvement/brand loyalty: is there a link?. Journal of product \& brand management, 12(1), 22-38.

Roca, J. C., Garcia, J. J., \& Vega, J. J. (2009). The importance of perceived trust, security and privacy in online trading systems. Information Management \& Computer Security, 17, 96-113.

Singh, J., \& Sirdeshmukh, D. (2000). Agency and trust mechanisms in consumer satisfaction and loyalty judgments. Journal of the Academy of Marketing Science, 28(1), 150-167.

Smith, T. J. (2008). Senior citizens and e-commerce websites: the role of perceived usefulness, perceived ease of use, and web site usability. Informing Science: The International Journal of an Emerging Transdiscipline, 11, 59-83.

Tatnall, A., \& Lepa, J. (2001). Researching the adoption of ecommerce and the internet by older people. In The $2^{\text {nd }}$ international We-B conference, Perth, Australia.

Tate, M.A. (2010). Web Wisdom How to Evaluate and Create Information Quality on the Web, 2, CRC Press.

Tan, F. B., \& Sutherland, P. (2004). Online consumer trust: a multi-dimensional model. Journal of Electronic Commerce in Organizations (JECO), 2(3), 40-58.

Trasorras, R., Weinstein, A., \& Abratt, R. (2009). Value, satisfaction, loyalty and retention in professional services. Marketing Intelligence \& Planning, 27(5), 615-632.

Welling, R., \& White, L. (2006). Web site performance measurement: Promise and reality. Managing Service Quality, 16, 664-670.

Yoon, S. J. (2002). The antecedents and consequences of trust in online-purchase decisions. Journal of Interactive Marketing, 16(2), 47- 63. 